\title{
土構造物の模型振動実験における相似則 \\ ON THE SIMILITUDE IN MODEL VIBRATION TESTS OF \\ EARTH-STRUCTURES
}

\author{
香川崇 章* \\ By Takaaki KAGAWA
}

\section{1.はじめに}

土構造物の振動性状，あるいは破壊性状を検討すると き，振動台による模型実験が行われることが多々ある. このような場合, 模型の挙動から実物のそれが推定でき るよう,これらの間に成り立つ可能な相似関係について 考慮するのが常である.

このような相似則に対する考察は古くは Galilei にま で逆のぼるといわれるが24)，土質力学の分野への適用は 比較的新しい. 適用例を挙げてみれば, ロック・フィル・ ダムの模型振動実験 ${ }^{3), 21)}$, 基礎の模型振動実験 ${ }^{51,10), 17), ~}$ 地下爆発のモデル化 ${ }^{2), 9)}$, 地下構造物のモデル化 ${ }^{27)}$, な どがあろう。また，わが国においてはさまざまな土構造 物の模型振動実験がこれまで行われてきている．これら の研究においては, 土を線形弾性体と仮定したり, ある いは土の破壊時の性状にのみ着目して相似則を立てる方 法がとられているが，こうして決定された相似則は土構 造物の非線形応答を調べるために行われる振動実験には 直接用いることができない.

このような研究とは別に静的な場合についてではある が, 土に対する相似則の開発を行った Rocha の研究 ${ }^{19), 20)}$ が注目される。彼は相似則を立てるために “模型に用い る材料は，実物のそれと同じ制約に従う相似な応力〜ひ ずみ関係を有するものとするが，応力およびひずみはす べて $1 / \alpha$ および $1 / \beta$ に縮尺されている”といら仮定を 導入した.この仮定に基づいて土中の間嚐水の移動があ る場合, および, ない場合の相似則を確立したが, 不飽 和土の場合生ずる毛管引力の影響については考慮しなか った.こうして求められた相似則は, ひずみと長さの縮 尺が異なっているため, $\beta=1$ の場合を除いて, 模型内 の変形が微小変形を仮定できないほど大きくなると適用 不可能となる. Rocha によって示されたこの方法は，こ れらいくつかの欠点を有するが，有用な概念を含んでい

* 正会員 Ph. D. McClelland Engineers, Inc.
るものと考えられる.

土構造物に対する相似則を立てる別の方法は，2つの 系（以下では模型と実物を意味する）での応力〜ひずみ 状態を等しくとるやり方である.この場合には模型にお いて重力の加速度あるいは材料の質量密度を形状の縮尺 に応じて変える必要が生じる. 前者は遠心力を利用して 模型内のみかけの重力の加速度を上げることにより達成 可能であるが, 後者は応力〜ひずみ関係がまったく同じ で質量密度のみ異なる材料を選択せねばならないという 理由からほとんど不可能である.しかしながら，この方 法のすぐれている点は相似則を立てるときに，その土の 応力〜ひずみ関係をくわしく検討する必要がないことで あろう・

一般に実際の土が振動実験に用いられた場合, 相似関 係は成立しにくいものと考えられてきたので, 振動実験 の結果からこれに対応する実物の挙動を直接推定された ことはほとんどなく, 振動台模型は単に “1つの小さな 実物”として実物からは切離して考えられるのが普通で あった．しかしながら，これは振動台の有意義な利用の ためには大きな制限を加えるものである.

そこで，本報告ではせん断ひずみ振幅に関する土のせ ん断定数, および減衰定数の非線形性を考慮に入れ, 土 構造物の振動性状を検討するための模型振動実験に適用 可能な相似則についての考察を行った.

\section{2. 相似則の立て方}

模型の中には，相似な形状を有する力学模型，特殊な 条件のもとにモデル化される力学模型, 形状的に相似で ない模型，などいくつかあるものと考えられるが，ここ では形状が相似な模型についてのみ考えることにする. このような場合には 2 つの系はその形状が相似で, これ ら 2 つの系に含まれるすべての物理量の比が定められた 縮尺に従らときに相似関係が成立する.すなわち、す心゙ ての物理量は $\pi$ とよばれる独立な無次元量によって関係 
づけられ，現象を取扱うらえで重要な物理量の数は大幅 に減少することになる．これらの $\pi$ こって，1つの系 からこれに相似な系への現象の変換が可能となり，1つ の系の挙動からもう1つの系のそれが簡単に求められる ことになる.このような意味で, 相似則を立てること は, 必要にしてかつ十分な無次元量を組立てることに帰 着する.

\section{（1） Buckingham の $\pi$ 定理を直接用いる方法}

この方法では第 1 亿，現象に関係すると考えられる物 理量をすべて列挙し, 第 2 に Buckingham $\pi$ 定理1) を用いて無次元量を組立て, そして第 3 にこれらの無次

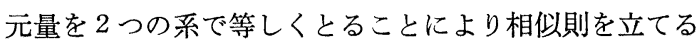
のである.

この方法は適用範囲が広く，一般によく用いられてい るが以下のような欠点を有している.

(a) ある無次元量をどのような条件のもとに無視して よいか, また，どの無次元量が大切であるかの判断をす る基準がない.

(b) 組立てられた無次元量は最初に列挙された物理量 いかんによって完全に決定されるし，また，物理量を列 挙するための確固たる方法が定められていない.

(C) 実際に必要な無次元量の数が $\pi$ 定理より求めたそ れより少なくなることがある.

そこで, Kline $\mathrm{e}^{13)}$ によって述べられた $\pi$ 定理を用いる 際の条件を参考として述べてみた.

(1) 列挙する物理量には, 現象に関係する独立な物理 量がすべて，そしてこれに従属な物理量が含まれていな ければならない。

(2) 組立てられた無次元量の中にはどの物理量も少な くとも 1 回は含まれていなければならない.

(3) 物理量を構成する次元量は互いに独立でなければ ならない.もしそうでないときは，このリダンダンシイ (redundancy) を考虑する必要がある.

\section{（2）力の比を用いる方法}

この方法は Fractional analysis に属し,19 世紀に力 学のさまざまな問題に適用された. どのような原因に基 ゔく力も同じ次元を有しているので, これらの力の間の 比をとることにより即座に無次元量が得られる. 相似則 を立てるためには，第 1 亿現象に関係する重要な力を列 挙し, 第 2 にこれら力相互の比をとり独立な無次元量を 求める. ここで無次元量の数は独立な力の数に等しくな る. そして, 第 3 にこれらの無次元量を 2 つの系で等し くとる.

これに等価な方法としては, 第 1 に現象に関係する重 要な力を列挙する. 第 2 に, それぞれの力について模型
と実物の比をとる. 第 3 に, これらの比をすべて等しく とる.この方法では無次元量を明白には取扱う必要がな くなる.

この方法の基礎となっている仮定は, “もし, 2 つの系 が形状的な, そして動力学的な相似を満足している場合 には, これらの系の挙動は相似であって,この条件は形 状が相似であり，2つの系の間でおもな力の比がすべて 同一であれば満足される”である. したがって，もし力 によらない物理量, たとえば熱伝導や電流を取扱う場合 には上記の仮定は満足されず，この方法を適用すること はできなくなる．このような理由で，この方法は多少一 般性に欠けることからあまり用いられていないようであ るが，力による物理量が支配的である問題に対しては有 効であると考えられる.

\section{（3）支配方程式を用いる方法}

現象を支配する方程式, およびその境界条件がわかっ ている場合にはさらに効率のよい相似則を立てることが できる.すなわち，このような方程式は 2 つの系に対し て同等に適用可能であって, これを無次元化することに より現象を支配する無次元量を抽出することができる.

相似則を得るためには, 第 1 亿支配方程式, および, これに対応する境界条件を無次元化することにより無次 元量を組立て, 第 2 にこれらの無次元量を 2 つの系で等 しくとればよい.

この方法は, 支配方程式が与えられた境界条件のもと に解くことが困難であり，これに対応する現象を実験的 に調べたいとき, 現象を左右する重要な無次元量を見つ けるうえできわめて有効な方法であろうと思われる.

\section{3. 土の応カ〜ひずみモデル}

かりに $2 つ の$ 系において応力の状態が等しくとられた 場合は，相似則を立てるうえで土の応力〜ひずみの関倸 を直接考虑する必要はないが, そうでなければ相似則を 立てる際にこの関係を導入しなければならない。そこ で,これまでに提案された土の応力〜ひずみ関係を近似 的に表現するモデルについてここで簡単に述べることに した.

\section{(1) Hyperbolic モデル}

粘性土に対する三軸圧縮試験の結果得られた偏差応力 と軸ひずみの関係を表現するために Kondner ${ }^{14)}$ が最初 に提案した. 後に Hardin-Drnevich ${ }^{8)}$ が, おもに共振 法土質試験から得られたせん断定数, および減衰定数の せん断ひずみ振幅に関する関係を近似するためにこのも デルを改良した. 


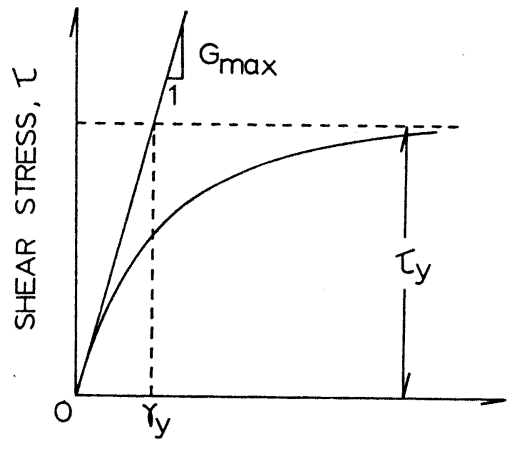

SHEAR STRAIN, $\gamma$.

Fig. 1 Stress-Strain Relationship of Soil

このモデルでは, せん断応力 $\tau$ はせん断ひずみ振幅 $r$ の関数として次式で近似されている.

$\tau=G_{\max } \cdot r /\left(1+r / r_{y}\right)$

上式に含まれる諸量を Fig. 1 に定義した. このモデ ルは 2 つパラメーターを含んでおり，これらによって 応力〜ひずみ関倸が完全に決定される. また，このモデ ルには極限せん断抵抗として $\tau_{y}$ が存在する.すなわち， せん断ひずみ振幅が無限大のときにもこれに対応するせ ん断応力は $\tau_{y}$ を越えることはない.

また, 減衰定数 $\beta$ は応力〜ひずみの描く履歴曲線によ って表わされるエネルギー損失を考慮することにより以 下のよらに求められた ${ }^{8)}$.

$$
\beta=\beta_{\max } \cdot\left(r / r_{y}\right) /\left(1+r / r_{y}\right)
$$

ここに, $\beta_{\max }$ はせん断ひずみ振幅が無限大のときの減 衰定数である.

\section{（2）一般化された Ramberg-Osgood モデル}

Ramberg-Osgood $^{18)}$ によって最初に提案され，Jennings $^{12)}$ によってさらに一般性を持たせるためにもう 1 つのパラメーターがつけ加えられた.

このモデルでは与えられたせん断応力からせん断ひず み振幅を次式によって求める。

$$
\left(r / r_{y}\right)=\left(\tau / \tau_{y}\right)+\alpha \cdot\left(\tau / \tau_{y}\right)^{r}
$$

ここで，応力〜ひずみ関係を近似するために 4 つのパラ メーターが用いられている. $r=1$ の場合には単なる線 形の，そして $r=\infty$ の場合には弾塑性の応力〜ひずみ 関係を表わすことができる.

減衰定数 $\beta$ を Jacobsen ${ }^{11)}$ によって述べられた等価 線形化法により求めれば,

$$
\begin{aligned}
& \beta=\beta_{\max } \frac{1-G / G_{\max }}{1-(r-1) G /\left(2 r G_{\max }\right)} ; \\
& \beta_{\max }=(r-1) / \pi r \ldots \ldots \ldots \ldots \ldots \ldots \ldots \ldots \ldots \ldots \ldots \ldots \ldots \ldots \ldots
\end{aligned}
$$

となる.ただし， $G / G_{\max }$ は次式より算定すればよい.

$$
\frac{G}{G_{\max }}=\frac{1}{1+\alpha\left(G \cdot \gamma / G_{\max } \cdot \gamma_{y}\right)^{r-1}}
$$

このモデルは, Constantopoulos4) や Papadakis ${ }^{16)} ら に$ よって地盤の地震态答解析に用いられたことがあるが, これまでおもに材料力学の分野で広く用いられてきたよ らである。

\section{（3） Hardin-Drnevich モデル}

Hardin-Drnevich ${ }^{8)}$ は Hyperbolic モデルを改良して このモデルを提案した. 彼らは, 多くの粘性土および砂 に対する共振法土質試験の結果求められたせん断定数, および減衰定数のせん断ひずみ振幅に関する関係を近似 するためにこのモデルを用いた.

せん断応力 $\tau$ は次式で表わされている.

$$
\tau=G_{\max } \cdot r /\left(1+\gamma_{h}\right)
$$

ここに, $r_{h}$ は hyperbolic strain とよばれ，

$$
r_{h}=\left\{1+a \cdot \exp \left(-b \cdot r / r_{y}\right)\right\} r / r_{y}
$$

で与えられている. $a$ および $b$ は実験的に求められる土 のパラメーターであって，このモデルは 4 つのパラメー ターによってその応力〜ひずみ関係を近似する.

また，減衰定数 $\beta$ は次式で与えられている。

$$
\beta=\beta_{\max } \cdot \gamma_{h} /\left(1+\gamma_{h}\right)
$$

$\beta_{\max }$ は非粘性土に対しては,おもにくり返し荷重の回数 に，また,粘性土においてはこれに加えて荷重速度，およ び応力状態によって左右されるものと考えられている.

\section{（4） Martin-Davidenkov モデル}

このモデルは Martin ${ }^{15)}$ によって提案されたが, Seed-Idriss によって提案されたせん断定数, および減衰定 数のせん断ひずみ振幅に対する関係 ${ }^{22)}$ をかなりよく近似 することができる.

応力〜ひずみ関係は次式で表わされている.

$$
\tau=G_{\max } \cdot\{1-H(\gamma)\} \cdot \gamma
$$

ここに, $H(r)$ は,

$$
H(r)=\left\{\frac{\left(r / r_{y}\right)^{2 B}}{1+\left(r / r_{y}\right)^{2 B}}\right\}^{A}
$$

と定義されており，このモデルには応力〜ひずみ関係を 近似するために 4 つのパラメーターが用いられている. $A=1, B=1 / 2$ とおけば,このモデルは Hyperbolic モ デルに帰着する.

また，減衰定数 $\beta$ は次式により算定できる。

$$
\begin{aligned}
& \beta=\beta_{\max } \frac{r^{2} \cdot H(\gamma)-2 \int_{0}^{\gamma} \eta \cdot H(\eta) \cdot d \eta}{\gamma^{2}-2 \int_{0}^{\gamma} \eta \cdot H(\eta) \cdot d \eta} ; \\
& \beta_{\max }=\frac{2}{\pi}
\end{aligned}
$$

\section{（5）一般的性質}

上記のモデルがどの程度土のせん断定数, および減衰 
表一1 モデルに用いたパラメーターの值

\begin{tabular}{l|llll}
\hline \multicolumn{1}{c|}{ Model Type } & \multicolumn{3}{|c}{ Values of Parameters } \\
\hline Hyperbolic Model & $r_{y}=3.16 \times 10^{-4}$ & & $\beta_{\max }=22 \%$ \\
Ramberg-Osgood Model & $r_{y}=3.16 \times 10^{-4}$ & $\alpha=2.5$ & $r=2$ & \\
Hardin-Drnevich Model & $r_{y}=3.16 \times 10^{-4}$ & $a=-0.5$ & $b=0.16$ & $\beta_{\max }=27 \%$ \\
Martin-Davidenkov Model & $r_{y}=3.16 \times 10^{-4}$ & $A=0.9$ & $B=0.413$ & \\
\hline
\end{tabular}

ターのみによって表わされる Hyperbolic モ デルがかなりよい結果を与えることに注目し たい.

ここでの目的は, このような土の応力〜ひ ずみモデルを相似則を立てる上で用いること が適切であるかどうかを検討することにあ
定数のひずみ依存性を近似しうるかについて調べるため に，各モデルで 表一1 に示したパラメーターの值を用 い, Seed-Idriss によって提案された砂に対するこれら の関係 ${ }^{22)}$ とを Fig. 2 に拉いて比較した.これから上記 のモデルはどれもかなり土のこれらの定数のひずみ依存 性を近似し得ることがわかる.ここで， 2 つのパラメー
る. この観点に立てば, 上記のモデルは土のせん断定 数, および減衰定数のひずみ依存性を近似するためには まず十分であるといえそうである.

そこで, 土の応力〜ひずみの関倸がこのようなモデル で近似できるものと仮定すれば, 土のせん断定数, およ び減衰定数は一般に次のように表現することができる.

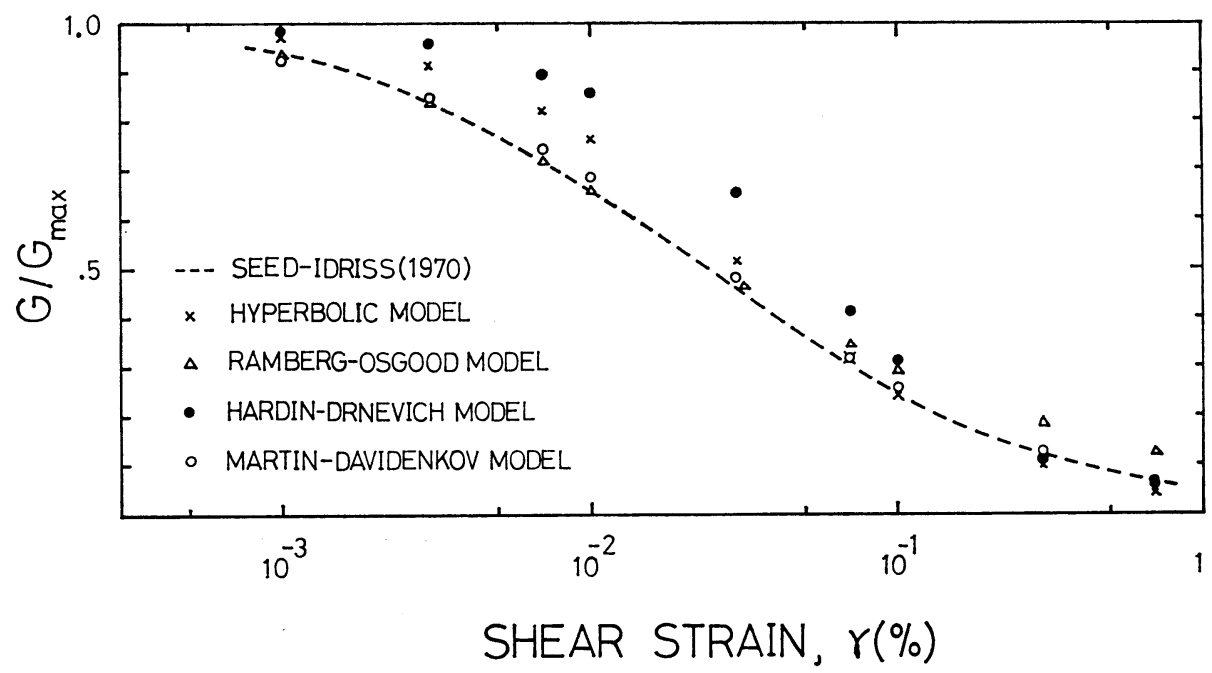

(a) Shear Modulus

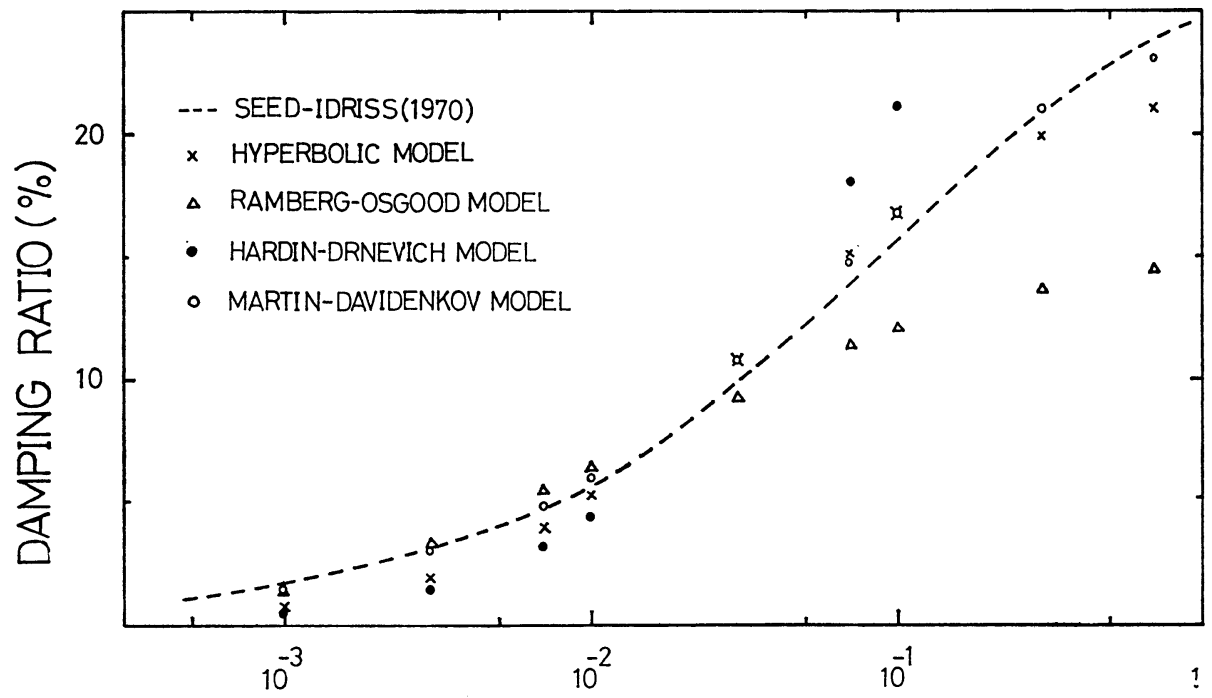

SHEAR STRAIN, $r(\%)$

(b) 1 Damping"Ratio

Fig. 2 Performance of Soil_.Models 


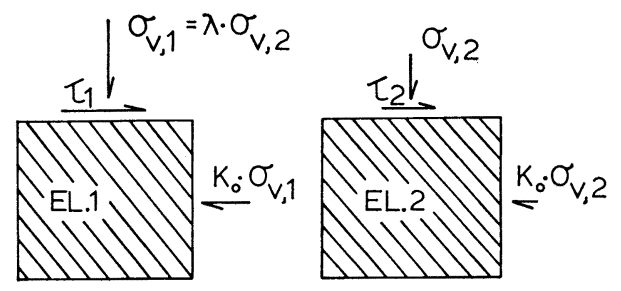

Fig. 3 Stress States in Model and Prototype Soil Elements

$$
\begin{aligned}
& G=G_{\max } \cdot F\left(r / r_{y}\right) \\
& \beta=\beta_{\max } \cdot f\left(r / r_{y}\right) \cdots
\end{aligned}
$$

ここで,これら定数のひずみ依存性に影響を与える環境 要素は関数 $F$, および $f$ の中に含まれている.また,降 伏せん断ひずみ振幅 $r_{y}$ はせん断ひずみ振幅 $r$ を正規化

するために用いられていて, 関数 $F$ および $f$ をその形 状を変えずに $r$ 方向一平行移動する役目を持っている.

ここで, Fig. 3 に示したような $K_{0}$ 状態にある $2 つ$ の土の要素を考えることにする.これらの要素はその有 効鉛直応力 $\sigma_{v, 1}, \sigma_{v, 2}$ が $\lambda$ 倍異なるだけで他の条件はす べて同一であるものとする. すなわち， $\sigma_{v, 1}=\lambda \cdot \sigma_{v, 2}$ で これらの要素のせん断抵抗 $\tau_{y}$ は初期応力状態のモール の応力円表示により, 次のように表わすことができる.

$$
\begin{aligned}
\tau_{y, 1}= & \left\{\left[\frac{\left(1+K_{0}\right)}{2} \sigma_{v, 1} \cdot \sin \phi_{1}{ }^{\prime}+c_{1}{ }^{\prime} \cdot \cos \phi_{1}{ }^{\prime}\right]^{2}\right. \\
& \left.-\left[\frac{\left(1-K_{0}\right)}{2} \sigma_{v, 1}\right]^{2}\right\}^{1 / 2} \\
\tau_{y, 2}= & \left\{\left[\frac{\left(1+K_{0}\right)}{2} \sigma_{v, 2} \cdot \sin \phi_{2}{ }^{\prime}+c_{2}{ }^{\prime} \cdot \cos \phi_{2}{ }^{\prime}\right]^{2}\right.
\end{aligned}
$$

$$
\left.-\left[\frac{\left(1-K_{0}\right)}{2} \sigma_{v, 2}\right]^{2}\right\}^{1 / 2}
$$

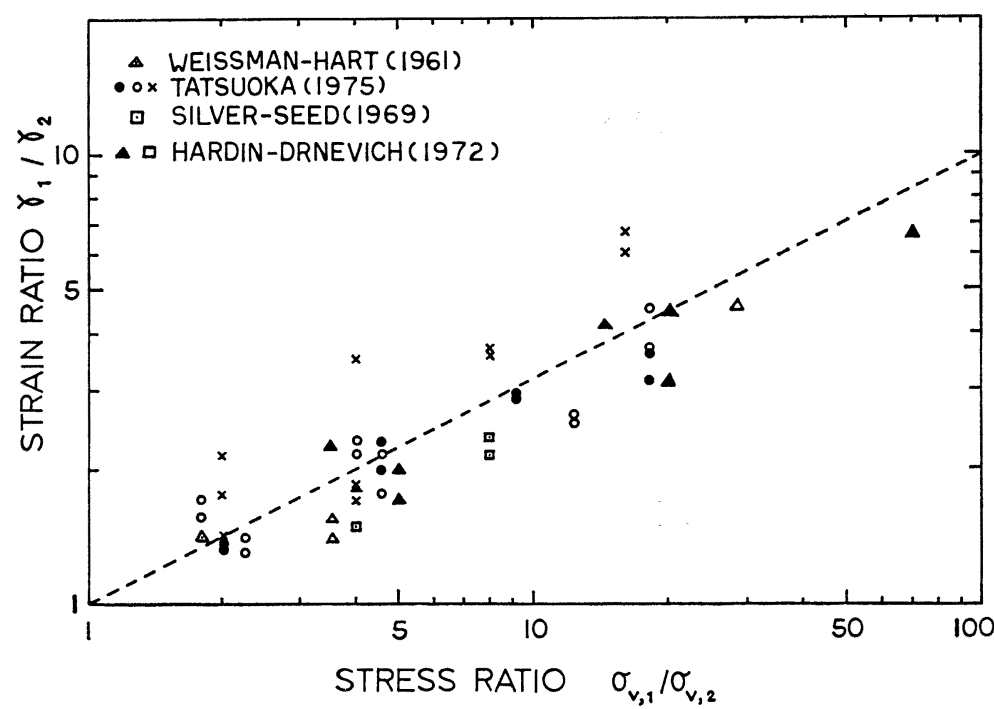

(a) Shear Modulus

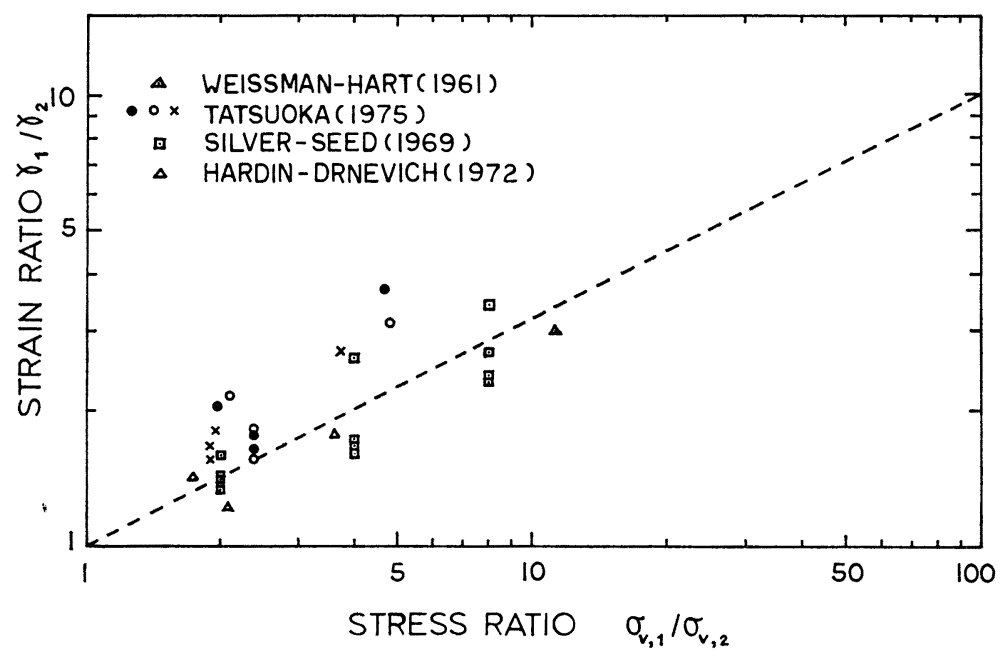

(b) Damping Ratio

Fig. 4 Validity of Eq. (15)
ここに, $K_{0}$ は静止土圧係数で, $c^{\prime}$ および $\phi^{\prime}$ は有効応力表示に よる土の静的強度を表わすパラ メーターである.いま, $K_{0}$ は 経験的に $\phi^{\prime}$ のみの関数として 表わされ, $\phi^{\prime}$ は 鉛直応力が極 度に高い場合を除けばこれに影 響されないものと考える.ま た, 粘着力 $c^{\prime}$ は砂や正規圧密 状態の粘土に対しては無視でき るものとすれば, $\tau_{y, 1}$ と $\tau_{y, 2}$ は次式で関係づけられることに なる。

$$
\tau_{y, 1}=\lambda \cdot \tau_{y, 2}
$$

過圧密状態の粘土では先行圧密 圧が 2 つの 土の要素で $\lambda$ 倍異 なっていれば以上の関係が近似 的に成立するものと思われる. 一方, 最大せん断定数 $G_{\max }$ は 有効平均主応力の平方根にほぼ 比例することが知られているの で, $G_{\max , 1}$ と $G_{\max , 2}$ は,

$$
G_{\max , 1}=\sqrt{\lambda} \cdot G_{\max , 2}
$$

したがって, 式 (12) および （13）から降伏せん断ひずみ $\gamma_{y, 1}$ および $\gamma_{y, 2}$ は， $r_{y, 1}=\sqrt{\lambda} \cdot r_{y, 2} \cdots \cdots(14)$

を満足することになる.

すなわち, “他の条件はすべ て同一でその鉛直応力のみが $\lambda$ 倍異なる $K_{0}$ 状態にある $2 つ$ 
の土の要素があった場合に，これらに対する $G / G_{\max }$, および $\beta / \beta_{\max }$ の曲線を考え, 同じ $G / G_{\max }$, および $\beta / \beta_{\max }$ の值を与えるせん断ひずみ振幅を $\gamma_{1}$, および $\gamma_{2}$ とすれば,

$$
r_{1} / r_{2}=\left(\sigma_{v, 1} / \sigma_{v, 2}\right)^{1 / 2}
$$

となる”ことが以上の考察より予測できる.

そこで, 以上の仮説が妥当なものであるかどうかを検 証するために他の研究者によって得られた土の剛性およ び減衰定数について, 実験時の条件がその鉛直応力のみ 異なる場合について, 同じ $G / G_{\max }$, および $\beta / \beta_{\max }$ の 值を与えるせん断ひずみ振幅の比 $\gamma_{1} / \gamma_{2}$ を, 対応する鉛 直応力の比 $\sigma_{v, 1} / \sigma_{v, 2}$ に対して Fig. 4 (a), (b) に示し た. 式 (15) が厳密に成立するものとすれば, 実験から 求められた点は Fig. 4 の破線上に位置するはずである が, 実際にはかなりのばらつきが見られる.しかしなが ら, 式（15）で仮定した関係はかなりよく成り立ってい るものと考えてよいであろう。

\section{4.土構造物の模型振動実験における相似則}

2. で述べたように Buckingham の $\pi$ 定理を直接用 いる方法からはあまりにも一般的な相似則が導びかれる ことになり，また，支配方程式を用いる方法では土の非 線形性, および破壊状態までを記述する方程式を求める こと自体が困難であると考えられるので, ここでは力の 比を用いる方法によって土構造物の模型振動実験に適用 可能な相似則を立てることにした。

土構造物の振動応答に影響を持っていると考えられる 力は, 慣性力, 弾性変形に伴う力, 内部摩擦減衰力, 自重 による力,そして土が破壊時に示す力などがあげられる. そこで，以下にそれぞれについて述べることにした。

\section{（1）慣性 力}

慣性力は質量 $M$, 振動数の平方 $\omega^{2}$, そして動的変位 $y$ の積として表わされるので, 2 つの系におけるこれら の力の比 $r_{i}$ は,

$$
r_{i}=\frac{M_{m}}{M_{p}} \cdot \frac{\omega_{m}^{2}}{\omega_{p}^{2}} \cdot \frac{y_{m}}{y_{p}}
$$

と表わされる.ここに，添字 $m$, および $p$ はそれぞれ 対応する物理量が模型, および実物に属するものである ことを示している.ここで, 質量密度 $\rho$, 動ひずみ $\varepsilon$, お よび 2 つ系の長さの比 $\lambda\left(=l_{p} / l_{m}\right)$ を導入すると,

$$
r_{i}=\frac{\omega_{m}^{2}}{\omega_{p}^{2}} \cdot \frac{\rho_{m}}{\rho_{p}} \cdot \frac{\varepsilon_{m}}{\varepsilon_{p}} \cdot \frac{1}{\lambda^{4}}
$$

となる.ただし, $\varepsilon=y / l$ である.

\section{（2）弾性変形に伴う力}

2 つの系での弾性力の比 $r_{e}$ は, 動ひずみ $\varepsilon$, 弾性定
数 $E$, および弾性応力の作用する面積 $A$ の比によって,

$$
r_{e}=\frac{E_{m}}{E_{p}} \cdot \frac{\varepsilon_{m}}{\varepsilon_{p}} \cdot \frac{A_{m}}{A_{p}}=\frac{E_{m}}{E_{p}} \cdot \frac{\varepsilon_{m}}{\varepsilon_{p}} \cdot \frac{1}{\lambda^{2}}
$$

と表わすことができる.

\section{（3）内部摩擦減衰力}

土の内部摩擦減衰力は一般に非速度依存型と考えられ ているので(6),7), 内部摩擦減衰力の比 $r_{d p}$ は, 減衰定数 $\beta$, 弾性定数 $E$, 動ひずみ $\varepsilon$, および弾性応力の作用する 面積 $A$ の比の積で与えられる.

$$
\begin{aligned}
r_{d p} & =\frac{\beta_{m}}{\beta_{p}} \cdot \frac{E_{m}}{E_{p}} \cdot \frac{\varepsilon_{m}}{\varepsilon_{p}} \cdot \frac{A_{m}}{A_{p}} \\
& =\frac{\beta_{m}}{\beta_{p}} \cdot \frac{E_{m}}{E_{p}} \cdot \frac{\varepsilon_{m}}{\varepsilon_{p}} \frac{1}{\lambda^{2}}
\end{aligned}
$$

\section{（4）自重による力}

2 つの系における自重による力の比 $r_{d}$ は, 質量密度 $\rho$, 重力の加速度 $g$, および体積 $V$ の比の積により次の ように与えられる.

$$
r_{d}=\frac{\rho_{m}}{\rho_{p}} \cdot \frac{g_{m}}{g_{p}} \cdot \frac{V_{m}}{V_{p}}=\frac{\rho_{m}}{\rho_{p}} \cdot \frac{g_{m}}{g_{p}} \cdot \frac{1}{\lambda^{3}}
$$

\section{（5）破壊時に示すカ}

かりに土のせん断抵抗 $\tau_{f}$ が次式のモール・クーロン の破壊基準に従うものとする.

$$
\tau_{f}=c^{\prime}+\sigma^{\prime} \cdot \tan \phi^{\prime}
$$

ただし， $\sigma^{\prime}$ は破壊面に作用する有効垂直応力である. 以 下では粘着力 $c^{\prime}$ および内部摩擦角 $\phi^{\prime}$ による力の比を 別々に考える. まず, 粘着力による力の比 $r_{c}$ は, 粘着 力 $c^{\prime}$ および破壞面の面積 $A^{\prime}$ の比の積で与えられる.

$$
r_{c}=\frac{c_{m}{ }^{\prime}}{c_{p^{\prime}}} \cdot \frac{A_{m}{ }^{\prime}}{A_{p^{\prime}}}=\frac{c_{m}{ }^{\prime}}{c_{p^{\prime}}} \cdot \frac{1}{\lambda^{2}}
$$

また, 内部摩擦角による力の比 $r_{f}$ は,

$$
\begin{aligned}
r_{f} & =\frac{\sigma_{m}{ }^{\prime}}{\sigma_{p^{\prime}}} \cdot \frac{A_{m}{ }^{\prime}}{A_{p^{\prime}}} \cdot \frac{\tan \phi_{m}{ }^{\prime}}{\tan \phi_{p}{ }^{\prime}} \\
& =\frac{\sigma_{m}{ }^{\prime}}{\sigma_{p^{\prime}}} \cdot \frac{\tan \phi_{m}{ }^{\prime}}{\tan \phi_{p}{ }^{\prime}} \cdot \frac{1}{\lambda^{2}} \cdots .
\end{aligned}
$$

で与えられる。

模型と実物を結びつける相似則は式 (16)〜 (21) で表 わされる力の比を等しくおくことにより求められる.す なわち, 次式が満足されればよい.

$$
r_{i}=r_{e}=r_{d p}=r_{d}=r_{c}=r_{f}
$$

ここで, 态力に対する縮尺 $\alpha$ と, ひずみに対する縮尺 $\alpha^{\prime}$ を導入することにする.

$$
\sigma_{p} / \sigma_{m}=\alpha, \varepsilon_{p} / \varepsilon_{m}=\alpha^{\prime}
$$

土構造物模型に対する相似則を立てるときよく用いられ る条件は $\alpha=\alpha^{\prime}=1$ であるので, まず最初にこの条件の もとにどんな相似則が導かれるかを検討してみよう。こ の場合, 2 つの系での応力〜ひずみ状態は等しく式 (16) 
〜 (21) は次式に帰着する.

$$
\left.\begin{array}{l}
r_{i}=\frac{\omega_{m}^{2}}{\omega_{p}^{2}} \cdot \frac{\rho_{m}}{\rho_{p}} \cdot \frac{1}{\lambda^{4}}, r_{d}=\frac{\rho_{m}}{\rho_{p}} \cdot \frac{g_{m}}{g_{p}} \cdot \frac{1}{\lambda^{3}} \\
r_{e}=r_{d p}=r_{c}=r_{f}=1 / \lambda^{2}
\end{array}\right\}
$$

ただし，2つの系で同じ応力状態なので, $E_{m}=E_{p}, \beta_{m}$ $=\beta_{p}, c_{m}{ }^{\prime}=c_{p}$, および $\phi_{m}{ }^{\prime}=\phi_{p}{ }^{\prime}$ が成立するものと考え た.したがって，相似則を得るための条件は，

$$
\frac{\rho_{m}}{\rho_{p}} \cdot \frac{g_{m}}{g_{p}}=\lambda, \frac{\omega_{m}^{2}}{\omega_{p}{ }^{2}} \cdot \frac{\rho_{m}}{\rho_{p}}=\lambda^{2}
$$

となり, 以下に述べる 2 つの相似則が得られる.

a) 相似則-A

かりに，模型において実物と同じ材料が用いられたと すれば, $\rho_{m}=\rho_{p}$ が満足されるので, 式 (25) から $g_{m} /$ $g_{p}=\lambda$, および $\omega_{m} / \omega_{p}=\lambda$ なる 条件が得られる. すなわ ち,この相似則では模型において実物と同じ質量密度を 有する材料が用いられたときには模型における重力の加 速度を入倍せねばならない.したがって，かりに $1 / 100$ の模型が製作されたとすれば，模型実験における重力の

\begin{tabular}{|c|c|}
\hline & 模型／実物 \\
\hline 振 動 数 & $\lambda$ \\
\hline 質量密度 & 1 \\
\hline 動的 変位 & $1 / \lambda$ \\
\hline 動ひずみ & 1 \\
\hline 応力 & 1 \\
\hline 加 速 度 & $\lambda$ \\
\hline
\end{tabular}

\section{表-2 相似則-A} 加速度は $100 \mathrm{~g}$ にまで増加する ことが必要となる.これは遠心 力を利用してみかけの重力の加 速度を増加させる実験方法をと ることにより達成可能ではある が, このような振動実験は現時 点では少なくとも不可能であろ う.この場合のおもな物理量の

縮尺を 表一2 に示した。

b) 相似則-B

次に, しし模型と実物において 同じ重力の場が用い られたとすれば, $g_{m} / g_{p}=1$ が満足され, 式 (25) より $\rho_{m} / \rho_{p}=\lambda$, および $\omega_{m} / \omega_{p}=\sqrt{\lambda}$ なる関係が求められる.

\begin{tabular}{|c|c|}
\hline & 模型／実物 \\
\hline 振 動 数 & $\sqrt{\lambda}$ \\
\hline 質量密度 & $\lambda$ \\
\hline 動 的变 位 & $1 / \lambda$ \\
\hline 動ひずす & 1 \\
\hline 応 力 & 1 \\
\hline 加 速 度 & 1 \\
\hline
\end{tabular}

\section{表-3 相似則-B}

この場合には模型において重 力の加速度を変える必要はない が，模型に用いられる材料は実 物のそれと同じ応力〜ひずみ関 係を有し，かつ，その質量密度 だけ入倍でなければならない. この条件は相似則-A において 強いられた条件よりさらに達成 不可能であろう. 表一 3 におもな物理量の縮尺を示し た.

c) 相似則-C

以上 2 つ相似則は 2 つ系での応力〜ひずみ状態が 同一であるといら条件のもとに導かれたが, これらは土 構造物の模型振動実験に適用されるためにはどちらも同 等に不適当であった.

いま，2つの系で同じ土が同じ条件のもとに用いら
れ, 模型において重力の加速度がコントロールできない ものとすれば次の条件はあらかじめ与えられていること になる.

$$
\sigma_{p} / \sigma_{m}=\lambda(=\alpha)
$$

したがって，相似則を得るためには土の応力〜ひずみ関 係を用いてひずみの縮尺 $\alpha^{\prime}$ を決定するしかない.ここ で，応力の比は式 (10) を用いて,

$$
\frac{\sigma_{p}}{\sigma_{m}}=\frac{G_{\max , p}}{G_{\max , m}} \cdot \frac{F\left(r_{p} / r_{y, p}\right)}{F\left(r_{m} / r_{y, m}\right)} \cdot \frac{r_{p}}{r_{m}}=\lambda
$$

と表わされ, さらに式 (13) を用いることにより, 上式 はひずみに対する縮尺 $\alpha^{\prime}$ を次のように与える.

$$
\alpha^{\prime}=\sqrt{\lambda}
$$

したがって, 式 (16)〜 (21) の力の比は,

$$
\left.\begin{array}{l}
r_{i}=\frac{\omega_{m}^{2}}{\omega_{p}^{2}} \cdot \frac{1}{\lambda^{4} \cdot \sqrt{\lambda}}, r_{d p}=\frac{\beta_{m}}{\beta_{p}} \cdot \frac{1}{\lambda^{3}} \\
r_{e}=r_{d}\left[=r_{c}=r_{f}\right]=1 / \lambda^{3}
\end{array}\right\}
$$

となる.ここで $r_{c}$ と $r_{f}$ をかっこに入れた理由は， 3. (5) で述べたように, 非粘性土や正規圧密状態にある 粘性土に対しては $c^{\prime}$ は無視することができ, $\phi^{\prime}$ は通常 対象とする上載圧の範囲ではこれによらないものと考え ると, $r_{f}=1 / \lambda^{3}$ であって $r_{c}$ について考える必要はない し, 式（10）および（11）で表わされる土の忘力〜ひず みモデルが破壊状態までも成立するものとすれば $r_{c}$ と $r_{f}$ を別途ここで考える必要がないからである.

次に内部減衰力の比 $r_{d p}$ であるが, 式 (11) を用い れば,

$$
r_{d p}=\frac{\beta_{\max , m}}{\beta_{\max , p}} \cdot \frac{f\left(r_{m} / r_{y, m}\right)}{f\left(r_{p} / r_{y, p}\right)}=\frac{\beta_{\max , m}}{\beta_{\max , p}} \cdots
$$

となる。 $\beta_{\max }$ は Hardin-Drnevich ${ }^{8)}$ によれば, 飽和 砂に対しては $\beta_{\text {max }}=28-1.5 \log N$, 飽和粘性土に対し ては, $\beta_{\text {max }}=31-\log N-(3+0.048 \omega) \cdot\left(\sigma_{m}\right)^{0.5}+0.60$ $(\omega)^{0.5}$ と与えられている. したがって, 非粘性土に対し てはくり返し荷重の回数 $N$ によってのみ多少影響され るだけで, $\beta_{\max , m}=\beta_{\max , p}$ がほぼ成立し, 粘性土に対 しては模型と実物の長さの縮尺が極度に大きくなり振動 数 $\omega$ の相違が大きく影響しない範囲で $\beta_{\max , m}=\beta_{\max , p}$ はほぼ満足されるものとみてよい.

したがって, すべての力の比は 円振動数 $\omega$ に関する 縮尺を

$$
\omega_{m} / \omega_{p}=\lambda^{3 / 4}
$$

ととることにより満足される.この場合のおもな物理量 の縮尺を 表-4 に示した.

ここで導いた相似則では，模 型において実物と同じ土，およ び同じ重力の場が用いられたと きに, すべての応力は $1 / \lambda に$ に そしてすべてのひずみは $1 / \sqrt{\lambda}$ に縮尺されることになり，この
表-4 相似則-C

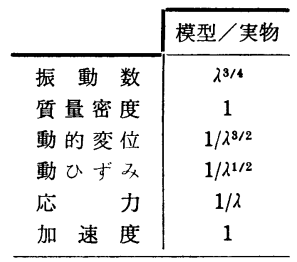


場合振動数は $\lambda^{3 / 4}$ 倍となることがわかった.したがっ て，振動台による模型実験のように重力の加速度を変え ることのできない場合にこの相似則が適用できることに なる.この相似則においてはひずみの縮尺が長さの縮尺 と異なっているが，士構造物模型の変形が微小であると 仮定できるときにはこれは問題とならない，ただ，変形 が極度に大きくなった場合には，ひずみと長さの縮尺が 異なっている影響が現われ相似則を乱すことになるが， 実物の土構造物の地震応答で考虑されるせん断ひずみ振 幅の範囲が $10^{-2} \sim 10^{-1} \%$ 程度であることを考えると， このために模型内に生ずるひずみは $\lambda=100$ の場合, $10^{-3} \sim 10^{-2} \%$ 程度であり，実物の土構造物で線形ひずみ 振動が仮定できるならば模型においても同様であり，ひ ずみと長さの縮尺が 2 つの系で異なっていることは問題 にならないものと思われる.

\section{5. 結論}

本報告では土構造物の模型振動実験を実際の土を用い て行う場合に適用可能な新しい相似則について考えてみ た.

これまで, 土構造物の模型振動実験のための相似則を 立てる場合，土が線形弹性体として扱えるものと仮定し たり，また，その破壊性状にのみ着目するのがほとんど であったそそうでない場合には振動台模型は実物との相 似関係から離れて “1つの小さな実物”として取扱わ れ，振動実験の結果は直接実物の挙動を推定するために は用いられず，実物で起こるであろう現象を定性的に再 現するため, あるいは, 設計計算に用いる解析手法の妥 当性を検証するためにのみ用いられてきたようである.

本報告における相似則では模型振動実験において実物 と同じ土を用いることができ，かつ，その重力の加速度 を変える必要もない，応力の縮尺は，模型で実物と同じ 土を用いるといら条件，および，模型において重力の加 速度を変えないといら条件から長さの縮尺に等しくすで に固定されたものと考え，ひずみの縮尺を土のせん断ひ ずみ振幅による非線形関係を用いて決定した。こうして 得られた相似則は, 土構造物の振動台による模型実験, 地盤〜構造物系の模型振動実験などに適用可能であり， 振動台実験によってこれら実物の非線形応答を直接推定 する方法を確立するために役立つものと考えられる.

\section{6.おわりに}

本報告は，筆者がカリフォルニア大学で行った $\mathrm{Ph}$. D. 研究の一部であり, 研究の遂行に 助力してくださっ た Lysmer 教授, および Seed 教授に 記してここに厚
くお礼を申し述べる次第である。

\section{参考 献}

1). Buckingham, E. : On physically similar systems, Phys. Rev. No. 4, 1914.

2) Chabai, J. : On scaling dimensions of craters produced by burried explosives, J. Geophysical Research, Vol. 70, 1965.

3) Clough, R.W. and D. Pirtz : Earthquake resistance of rock-fill dams, Trans. Am. Soc. Civ. Eng. Vol. $123,1958$.

4) Constantopoulos, I.V., J.M. Roesset, and J.T. Christian : A comparison of linear and exact nonlinear analyses of soil amplification, Proc. 5th World Conf. Earthquake Eng., Rome, 1973.

5) Hadala, P.F. : Dynamic bearing capacity of soils, investigation of a dimensionless load-displacement relation for footings on clay, Waterways Experiment Station Technical Report 3-599, Vicksburg, Miss., June, 1965 .

6) Hardin, B.O. and W.L. Black : Sand stiffness under various triaxial stresses, J. Soil Mech. Fdns. Div., ASCE, Vol. 92, No. SM 2, Mar., 1966.

7) Hardin, B.O. and W.L. Black : Closure to Vibration modulus of normally consolidated clays, J. Soil Mech. Fdns. Div., ASCE, Vol. 95, No. SM 6, Nov., 1969.

8) Hardin, B.O. and V.P., Drnevich : Shear modulus and damping in soils; Design equations and curves, J. Soil Mech. Fdns. Div., ASCE, Vol. 98, No. SM 7, July, 1972.

9) Haskell, N.A. : Some consideration on the modeling of crater phenomena in earth, Air Force Surv. Geophys., Vol. 67, TN 55-205, Air Force Cambridge Research Center, Bedford, Mass., 1955.

10) Jackson, J.G. and P.F. Hadala : Dynamic bearing capacity of soils, Report 3, the application of similitude to small-scale footing tests, Waterways Experiment Station Technical Report No. 3-599, Vicksburg, Miss., Dec., 1964.

11) Jacobsen, L.S. : Damping in composite structures, Proc. 2nd World Conf. Earthquake Eng., Tokyo, 1960.

12) Jennings, P.C. : Periodic response of a general yielding structure, J. Eng. Mech. Div., ASCE, Vol. 90, No. EM 2, April, 1964.

13) Kline, S.J. : Similitude and Apporoximation Theory, McGraw-Hill Book Co., 1965.

14) Kondner, R.L. : Hyperbolic stress-strain response; cohesive soils, J. Soil Mech. Fdns. Div., ASCE, Vol. 89, No. SM 1, Feb., 1963.

15) Martin, P.P. : Non-linear methods for dynamic analysis of ground response, Ph.D. Thesis, University of California, Berkeley, June, 1975.

16) Papadakis, C. N., V. L. Streeter and E. B. Wylie : Bedrock motions computed from surface seismograms, J. Geotech. Eng. Div., ASCE, Vol. 100, No. GT 10, Oct., 1974.

17) Poplin, J.K. : A model study of dynamically loaded square footings on dry sand, Waterways Experiment Station Technical Report 69-3, Vicksburg, Miss., March, 1969.

18) Ramberg, W. and W.R. Osgood : Description of stress-strain curves by three parameters, Technical Note 902, NACA, July, 1943. 
19) Rocha, M. : Similarity conditions in model studies of soil mechanics problems, Laboratoria Nacional de Engenharia Civil, Lisbon Publ. No. 35, 1953.

20) Rocha, M. : The possibility of solving soil mechanics problems by the use of models, Proc. 4th Int. Conf. Soil Mech., London, Vol. 1, 1957.

21) Seed, H.B. and R.W. Clough : Earthquake resistance of sloping core dams., J. Soil Mech Fdns. Div., AS CE, Vol. 89, 1963.

22) Seed, H.B. and I.M. Idriss : Soil moduli and damping factors for dynamic response analysis, Report No. EERC 70-10, Earthquake Eng. Research Center, University of California, Berkeley, Dec. 1970.

23) Silver, M. L. and H. B. Seed : The behavior of sands under seismic loading conditions, Report No. EERC 69-16, Earthquake Eng. Research Center, University of California, Berkeley, Dec., 1969.

24) Sommerfeld, A. : Mechanik der Deformierbaren Medien, 4th ed., Akad. Verlagses, Leipzig, 1957.

25）龍岡文夫：利根川砂の動的変形倸数， 1975 年 2 月 20 日.

26) Weissman, G.F. and R.R. Hart : The damping capacity of some granular soils, Symposium on capital Dynamics, ASTM Special Technical Publication, No. 305, June, 1961.

27) Young, D.F. and G. Murphy : Dynamic similitude of underground structures, J. Eng. Mech. Div., ASCE, Vol. 90, No. SM 3, June, 1964.

(1977.4.18 · 受付) 